\title{
Managing diversity: is Australia bucking the post- multiculturalist trend or on its way to embrace interculturalism?
}

\author{
Maren Klein \\ Swinburne University of Technology, Australia \\ mklein@swin.edu.au
}

\begin{abstract}
At a time when multiculturalism as an approach to managing diversity in society has been declared a failed policy in many western countries, Australia still seems committed to the approach as evidenced in public discourse and government declarations. The concept of interculturalismpromoted as a more appropriate approach to dealing with diversity in other parts of the world such as Europe and Canada - seemingly has no place in the Australian context. However, changes in the understanding of the concept, its application and degrees of commitment to it can also be observed in Australia. Not only has the meaning and execution of multiculturalism changed considerably over the years, there has also been vigorous debate and backlash, embodied in the political arena, by the (re) emergence of parties, and more recently, a variety of groupings with a nationalistic and/or nativist focus. More generally, a hardened attitude in public discourses concerning migration, social cohesion and national identity has developed over the last two decades. In the context of these developments, this article will trace the evolution of the Australian concept of multiculturalism and its concrete application focussing on the changes of the last two decades. A comparison of Australia's purportedly unique type of multiculturalism and concept(s) of interculturalism to explore whether Australia's nation-building project is indeed distinct from other countries' diversity experience, or whether there is a place for interculturalism in Australia in an era of increasing mobility will conclude the article.
\end{abstract}

Keywords: Australia, Europe, North America, Interculturalism, Multiculturalism

\section{Introduction}

Growing global mobility of people and increasingly 'permeable' nation-state boundaries in countries produce ever more culturally diverse societies ${ }^{1}$. According to the United Nations Population Division², between 1990 and 2000, the international migrant stock grew by an average of 1.2 per cent per year. Between 2000 and 2010 it accelerated to 2.3 per cent. The impact of the General Financial Crisis (GFC) resulted in a temporary slowdown to around 1.6 per cent per year during the period 2010 to

\footnotetext{
${ }^{1}$ Mansouri, F. \& Lobo, M. 2011, 'Introduction: Social Inclusion: Exploring the Concept,' in F. Mansouri, \& M. Lobo (eds.), 2011. Migration, Citizenship, and Intercultural Relations: Looking Through the Lens of Social Inclusion. Ashgate Publishing, Ltd., p. 1

2 United Nations 2013, International Migration Report 2013, Department of Economic and Social Affairs, New York.
} 
2013. In the Organisation for Economic Co-operation and Development (OECD) area, a reversal of this trend became noticeable in 2014. Migration to OECD countries increased again in 2015 and is now above the peak level of 20073. The increase is observable in permanent as well as temporary migration flows. Permanent migration to OECD countries increased by 4.3 per cent in 2014, a four per cent increase on 2013, and preliminary data for 2015 suggests that there was an increase of ten per cent in permanent migrant numbers during that period. Temporary migration through inter-company mobility within the European Union and the European Free Trade Area rose by 17 and 38 per cent respectively.

The inclusion of ethnic minority groups always presents opportunities and challenges to host countries. The terrorist attacks of 9 September 2001 on the World Trade Centre in New York in particular caused a shift in public discourses on managing diversity in society from the gains reaped through migration to the challenges posed by migrants, with public discourses and media coverage focused on terrorist acts and racial violence, and cultural diversity increasingly linked to fears of terrorism, vulnerability, and alienation ${ }^{4}$.

As societies become increasingly diverse, a demographic trend forecast to continue, it has been argued that diversity itself is set to become so common it will be considered mainstream. This means that one of the central questions for contemporary societies has shifted from 'how to live with diversity' to how to live together in diversity'5, thus acknowledging diversity as a feature of modern societies. In this context, the assumed homogeneity of majority cultures, characterised by a native majority with homogeneous ethnic, cultural and societal traits is increasingly questioned ${ }^{6}$.

Living 'in' diversity, as Antonsich argues, is a more useful concept than living 'with' diversity because it presupposes tolerance. Yet, tolerance itself is a deeply problematic concept, being imbued with an uneven power relation. As a matter of fact, 'tolerance always presupposes a control over what is tolerated'"'7.

Two contemporary, commonly utilised but contested policy approaches to manage diverse contemporary societies are interculturalism and multiculturalism. However, over the past few decades there has been much discussion and vigorous debate regarding the relative merits and benefits of the concepts, mostly concentrated in Europe and North America. Proponents of interculturalism ${ }^{89}$ assert that their approach is better suited to addressing diversity in contemporary societies and the hybridisation of identities, that is in an era of unprecedented mobility individuals have a number of different and context-dependent identities which may include ethnic ascriptions.

\footnotetext{
3 OECD (2016), International Migration Outlook 2016, OECD Publishing, Paris.

DOI: http://dx.doi.org/ 10.1787/ migr_outlook-2016-en

4 Mansouri. F. \& Lobo, M., 2011, p. 1.

${ }^{5}$ Antonsich, M., 2015. 'Interculturalism versus multiculturalism- The Cantle-Modood debate.' Ethnicities, 16(3), pp.470-49, p. 1.

6 Bean, FE \& Brown SK 2014, 'Demographic analyses of immigration', in CB Brettell \&J F Hollifield (eds), Migration theory: Talking across disciplines, $3^{\text {rd }}$ edn, Taylor and Francis, EBL ebook library, pp. 67-89, p. 75.

${ }^{7}$ Hage, G., 2000, cited in Antonsich 2015, p. 1.

8 Cantle, T., 2012, 'Interculturalism: for the era of globalisation, cohesion and diversity.' Political Insight, 3(3), pp.38-41.

9 Cantle, T., 2015. 'National identity, plurality and interculturalism.' The Political Quarterly, 85(3), pp.312-319.
} 
Thus, while it seems that multiculturalism is seen as a failed policy approach in the European political arena, ${ }^{10}$ Australia still seems committed to multiculturalism. In a speech to the Sydney Institute on 9 March 2016, the Australian Race Discrimination Commissioner, Tim Soutphommasane, argued that multiculturalism in Australia was a success; and it was a success because the Australian model of multiculturalism differed substantially from European approaches. Crafted in the 1970s, informed by the experiences of incorporating large groups of migrants after World War 2, Australian multiculturalism is an acknowledgement of cultural diversity, of a common identity not based on ethnic terms but the demographic evolution of the Australian population:

Australia's multicultural success has been predicated on Australian society accepting immigration as a nation-building project. In many countries, immigration occurred without planning. But that wasn't the case here. A wellordered immigration program has ensured public acceptance of cultural diversity; it has underpinned the cultural generosity of Australian society. ... It means a national community defines its national identity not in ethnic or racial terms, but in terms that can include immigrants. It means a national community accepts that its common identity may evolve to reflect its composition. ${ }^{11}$

However, multiculturalism is not an uncontested concept or practice in Australia either ${ }^{12}$. It was questioned and denounced as undermining Australia's cultural values as early as 1984, when historian Geoffrey Blainey decried the "Asianisation of Australia"13. In the current climate the focus has shifted from the Asian to the Muslim 'Other' as exemplified by the One Nation Senator Pauline Hanson'14, who in the 1990s focused on Asians (and Indigenous Australians) and on her return to politics targeted Muslims, tapping into and echoing public discourses which view Islam as incompatible with western values. It has also been argued that the 1996 election of a conservative government led by J ohn Howard heralded the Australian retreat from multiculturalism and a return to a pro-white British mindset with the absorption of many migrant services and institutions into main stream services. On a conceptual level, the 1999 New Agenda for Multicultural Australia redefined the principles of multiculturalism from one of support for ethnic groups and migrants to one with an emphasis on national values, civic duty, and integration into mainstream culture.

This shift found its representation in the introduction of the 2007 Citizenship test as a means for societal cohesion and migrant integration ${ }^{1516}$. Australia's policy here followed the international trends involving reassertion of the nation-state17.

\footnotetext{
10 Three European leaders-Angela Merkel (Germany) in October 2011, David Cameron (UK) in February 2011, and Nicolas Sarkozy (France) also in February 2011- have publicly denounced its failure.

${ }^{11}$ Soutphommasane, T. 2016, "The Success of Australia's Multiculturalism." Speech to the Sydney Institute, 9

March 2016, <https:// www.humanrights.gov.au/ news/ speeches/ success-australia-s-multiculturalism>, accessed on 15 August 2016.

12 Ang, I. \& Stratton, J ., 1998, 'Multiculturalism in crisis: The new politics of race and national identity in Australia.' TOPIA: Canadian J ournal of Cultural Studies, (2).

${ }^{13}$ Castles, S., Vasta, E. \& Ozkul, D., 2014, 'Australia: A classical immigration country in transition', in J F Hollifield, PL Martin \& PM Orrenius (eds), Controlling immigration: A global perspective, Stanford University Press, Stanford, CA, pp. 128-150.

${ }^{15}$ Ho, C., 2013, 'From social justice to social cohesion: A history of Australian multicultural policy', in A. J akubowicz \& C. Ho (eds.), "For those who've come across the seas ...": Australian multicultural theory, policy and practice, Australian Scholarly Publishing, North Melbourne, pp. 31-41.
} 
Moreover, the same critiques of multiculturalism as seen in Europe, a set of interconnected and/ or nested negative beliefs, the so-called "backlash tropes"18, can be observed in contemporary Australian public discourses as well. One of these posits that multiculturalism - a single and unified ideology imposed by native liberals and ethnic activists -, suppresses the ability to point out any problems or issues in relation to migrants and ethnic minorities through the tool of political correctness: for instance, any criticism of multiculturalism is branded 'racist', thus precluding debate. Another claim is that multiculturalism endorses segregation by not privileging the host culture over any minority culture. This is said to promote ethnic separateness, through the absence of common national values and no incentives for social integration. Another trope is that of cultural relativism, i.e. multiculturalism supports reprehensible practices such as forced marriage and honour killings. Finally, multiculturalism is decried for creating a breeding ground for terrorism through the cultural vacuum of no common values; which is claimed to provide terrorist groups with fertile ground for indoctrination of disaffected minority group members ${ }^{19}$.

The similarities of the public discourses then pose the question whether Australian multiculturalism is truly different as proclaimed by the Australian Race Discrimination Commissioner. At the same time, this opens a debate about the merits of multiculturalism and interculturalism, and poses the question whether the era 'post-multiculturalism'20 while well underway in Australia has simply not yet been acknowledged. This article will explore this question by first investigating the concepts of multiculturalism and interculturalism including critiques levelled at each, followed by a brief exploration of the development of multiculturalism in select European countries, and contrasting it with the development in Australia. The conclusion will explore some ideas why multiculturalism is pronounced a success in Australia but branded an outdated concept in Europe and North America.

\section{A brief exploration of the concepts}

\section{Multiculturalism}

Despite the fact that the term "multiculturalism" is often taken to mean one well delineated particular ideology, in reality there is no single or simple definition, in particular when investigating the domain of policies and institutions. According to Barrett ${ }^{21}$ the concept of multiculturalism refers to policy approaches to managing culturally diverse societies. Cultural diversity can arise from a number of key factors: there may be indigenous or regional minorities (e.g. Basques in Spain, Kurds in Turkey, Sami in Finland, Aboriginals in Australia, Maori in New Zealand, Inuit in Canada); there may be long-settled minority groups (e.g. Franco-Canadians); changes in nation-state borders (e.g. the various nation-states which made up the former USSR or former Yugoslavia); migration which itself can have a number of

\footnotetext{
16 Wende, A.-K., 2010, German migrants in Western Australia and Queensland: Acculturation and transnational social spaces, Südwestdeutscher Verlag für Hochschulschriften, Saarbrücken, Germany.

${ }^{17}$ Klapdor, M., Coombs, M. \& Bohm, C., 2009, Australian citizenship: A chronology of major developments in policy and law, Australian Government Public Service, Canberra, pp. 18-19.

${ }_{18}$ Vertovec, S. \& Wessendorf, S. 2010. 'Introduction: assessing the backlash against multiculturalism in Europe.' In S. Vertovec \&S. Wessendorf (eds) 2010, Multiculturalism backlash: European discourses, policies and practices. Routledge, p. 10.

${ }^{19}$ Vertovec \&Wessendorf, 2010, pp. 6-12.

${ }^{20}$ Kymlicka, W., 2010, The rise and fall of multiculturalism? New debates on inclusion and accommodation in diverse societies.' International social science journal, 61(199), pp.97-112.

${ }^{21}$ Barrett, M. (ed.), 2013. Interculturalism and multiculturalism: similarities and differences. Council of Europe.
} 
different causes. However, multiculturalism is often taken to refer to diversity through migration only. Definition is further complicated by the fact that governments in general have not approached incorporation of ethnic minorities and migrants with a set of well-ordered policies and tools but through a variety of often ad hoc strategies, measures and practices. Approaches may vary depending on locality so that even within the same country different localities may employ different strategies $^{22}$.

According to Kymlicka the origins of the contemporary concept of multiculturalism can be traced back to western liberal democracies, the emergence of a human rights focus after World War II and an ideology of "racial and ethnic equality"23 in the late 1960s. By focussing on human rights and equality, multiculturalism attempts to provide a framework to address ethnic and racial hierarchies and the inequalities arising from those hierarchies. Its application and development is context-specific depending on the country specific population(s), immigration history, and on the way ethnic minority groups wish to be recognised. Therefore the policies adopted will differ significantly from country to country. Moreover, multiculturalism approaches evolve in response to societal shifts and developments, making it not only context specific on a geographical level but also on a historical one. Ultimately, multiculturalism is about ensuring the adoption of legal frameworks which allow members of minority groups to retain their ethnic identities including beliefs and practices, rather than assimilation into the majority group.

Kymlicka ${ }^{24}$ distinguishes three types of multiculturalism in western democracies. Firstly, an empowerment of indigenous groups can be observed. This may include but is not limited to policies in relation to land rights, recognition of self-governing and cultural rights, and affirmative action. Secondly there are new forms of autonomy for regional minority groups such as the Basques and Catalans in Spain with policies in relation to territorial autonomy, official language status, guarantees of representation in central government. And third, new forms of multicultural citizenship for immigrant groups can be observed, which may include policies areas such as in education (i.e. inclusion of migrant language instruction, funding of ethnic support organisations and legal measures supporting inclusion).

Barrett 25 also identifies three main forms: symbolic, structural, and dialogical multiculturalism. Symbolic multiculturalism, sometimes called the 35 model of multiculturalism (saris, samosas, and steel drums) ${ }^{26}$, focuses on the symbolic markers of ethnic cultures such as costume or food and singles them out for celebration. This essentially is problematic because it reinforces a view of culture as trivial, inexorable and immune to change. It also obscures the fact that not all aspects of ethnic cultures are acceptable to the host culture, inviting the criticism of moral relativism. Moreover, it tends to reinforce unequal power structures within ethnic groups.

Structural multiculturalism is concerned with establishing systems to counter discrimination, involving allocation of nation-state resources to achieve equity for

\footnotetext{
22 Freeman, G.P., 2004. 'Immigrant incorporation in western democracies'. International migration review, 38(3), pp.945-969, p. 946.

${ }^{23}$ Kymlicka 2010, p. 100.

${ }^{24}$ Kymlicka 2010, p. 101.

${ }^{25}$ Barrett 2013. p. 20.

${ }^{26}$ Alibhai-Brown, Y., 2000. After multiculturalism. Foreign Policy Centre.
} 
minority groups. The underlying assumption here is that recognition of minority groups can only be effective in a system where power structures grant minority groups the same status as the majority group.

Dialogical multiculturalism is an ideal of how multiculturalism should operate. It acknowledges that the composition of contemporary societies has to accommodate a number of cultures whose interaction should involve open dialogue in the political and non-political spheres of life. To enable such a dialogue, normative structure, delineating constitutional, legal and civic values, are required.

According to Meer and Modood ${ }^{27}$ multiculturalism as interpreted in Europe, and the English speaking world more broadly (but see Wiewiorka ${ }^{28}$ for a critique of this perspective) represents "the political accommodation by the State and/ or a dominant group of all minority cultures defined first and foremost by reference to race, ethnicity or religion, and, additionally but more controversially, by reference to other group-defining characteristics such as nationality and aboriginality".

As outlined in the so-called "backlash tropes", a number of critiques have been levelled at multiculturalism. Kymlicka ${ }^{29}$ observes that critiques of multiculturalism, and the "retreat" from it, usually revolve around diversity through migration, and under conditions where immigrant groups are viewed as a particular high risk in relation to socio-economic interests (e.g. a burden on the welfare net) or ethical principles ('illegal immigrants'). He further contends that even when a retreat can be observed it may not be spread evenly across all locations, or may indeed be counteracted in particular locales. He cites the example of Australia where, while the federal Liberal Party government retreated from multiculturalism, a number of state Labor governments introduced their own multiculturalism policies ${ }^{30}$.

The more substantive critiques include that not privileging the host culture and instead viewing all cultures as equally valid leads the establishment of parallel communities with members of different cultures leading separate lives within their own communities, with little interaction breeding ignorance and mistrust. It has also been claimed that not privileging the majority culture weakens national identity, loyalty, common values and social cohesion, and by extension provides a breeding ground for terrorism. Moreover, multiculturalism leads to moral relativism as it supports minority practices which may be culturally unacceptable; and that it stifles debate about societal problems related to migrants by branding any criticism as racist. A fourth charge made against multiculturalism is that it institutionalises cultural differences by viewing culture as static, ignoring the fact that culture is fluid evolving and forever internally heterogeneous. Finally, multiculturalism has been considered an outdated concept as it does not take into account the fluidity and hybridism of contemporary identities ${ }^{31}$.

\footnotetext{
${ }^{27}$ Meer, N. \& Modood, T., 2012, 'How does Interculturalism Contrast with Multiculturalism?', J ournal of Intercultural Studies, 33 (2), pp. 175-196, p. 175.

${ }^{28}$ Wieviorka, M., 2012, 'Multiculturalism: A Concept to be Redefined and Certainly Not Replaced by the Extremely Vague Term of Interculturalism', J ournal of Intercultural Studies, 33 (2), pp. 225-231.

${ }^{29}$ Kymlicka, W., 2010, pp. 105-108.

30 See for instance the New South Wales Community Relations Commission and Principles of Multiculturalism Act 2000 (NSW), drafted in response to the debate about the concept of multiculturalism. In Victoria, the principles of multiculturalism are contained in the Multicultural Victoria Act 2004 (Vic) (Koleth, E., 2010). ${ }^{31}$ Meer, N. \& Modood, T., 2012.
} 
It is in particular this last claim, which is put forward by proponents of interculturalism as a more suitable approach to manage diversity. Cantle for instance argues that identity based on exclusivity is on the wane:

We fail to provide an intercultural education, in which people have the opportunity to come to terms with the way in which the world is changing and insist on an identity classification system based on exclusivity. As an example of this, I often cite a young woman who has described her many identities - as 'a Glaswegian, Pakistani teenager of Muslim descent who supports Glasgow Rangers in a Catholic school'. 32

For Cantle, this is an example of the ubiquity of hybridisation of identity and the plurality of contemporary society which multiculturalism cannot adequately address.

\section{Interculturalism}

The 2008 'White Paper on Intercultural Dialogue' of the Council of Europe was instrumental in introducing the concept of interculturalism to a broader (but mainly European) audience. It sets out the concept of intercultural dialogue using the following definition:

... a process that comprises an open and respectful exchange of views between individuals and groups with different ethnic, cultural, religious and linguistic backgrounds and heritage, on the basis of mutual understanding and respect. ...... It aims to develop a deeper understanding of diverse world views and practices, to increase co-operation and participation (or the freedom to make choices), to allow personal growth and transformation, and to promote tolerance and respect for the other. 33

Brahm Levey) ${ }^{34}$ differentiates between "hard" and "soft" claims. While proponents of "hard" claims of interculturalism see it as completely different-and superiorapproach to govern diversity in contemporary societies ${ }^{35}$, there are other, "soft", positions which view the two concepts as emphasising different aspects ${ }^{36}$. Meer and Moodod 37 understand interculturalism as a subset of multiculturalism while Kymlicka ${ }^{38}$ puts forward the idea that political expediency might have played a role in switching terms in the public discourse as multiculturalism had become politically tainted. Cantle 39 for instance, points to the complex hybridity of contemporary identities and how these are influenced and fore- or backgrounded depending on context.

Proponents of interculturalism also point out that in an age where mobility is common and multidirectional, mobile people do not necessarily identify along a continuum of ethnicity, making multiculturalism an approach more suited to an era

\footnotetext{
32 Cantle 2015, p. 7.

33 Council of Europe 2008. White Paper on Intercultural Dialogue "Living Together as Equals in Dignity". Launched by the Council of European Ministers of Foreign Affairs at their 118th Ministerial Session (Strasbourg, 7 May 2008), Strasbourg Cedex., p. 17.

34 Brahm Levey, G. 2012, 'Interculturalism vs. Multiculturalism: A Distinction without a Difference,' J ournal of Intercultural Studies, 33 (2), pp. 217-224, p. 218.

35 See for instance Cantle, T., 2012, 2015; Counsel of Europe, 2008.

36 Barrett, M., 2013, p.15.

${ }^{37}$ Meer, N. \& Moodod, T. 2012.

38 Kymlicka, W., 2012, 'Comment on Meer and Modood', J ournal of Intercultural Studies, 33(2), pp. 211-216, p. 215

39 Cantle, T., 2015.
} 
of mobility geared towards permanent settlement. ${ }^{40}$ It is worth noting that interculturalism shares a number of features with multiculturalism. It values cultural diversity and pluralism and advocates social inclusion and integration. Inclusion is viewed as a process working both ways, that is majority and minority group(s) make adjustments to accommodate each other through a process of respectful communication. Interculturalism also acknowledges the existence of underlying systemic issues such as political, economic and social disadvantage. Thus, it builds on the features of multiculturalism.

A central focus in interculturalism, though, is on dialogue, interaction and exchange considered to lead to a deeper understanding and acceptance of different cultures and to foster the evolution of a new shared and common culture and thus a cohesive society, thus addressing one of the purported shortcomings of multiculturalism. Other approaches such as that adopted by the Council of Europe's 'White Paper' (2008) contend that the values an intercultural approach is based on are the rule of law and universal human rights. From this perspective not all cultural practices of minority groups are acceptable, thus avoiding one of the issues multiculturalism is criticised on, namely that of moral relativism.

Interculturalism relies on education: it requires the development of intercultural skills such as open-mindedness, the ability to communicate and adapt one's behaviour to cultural practices, empathy and cognitive flexibility. These skills, according to the Council of Europe's 'White Paper' (2008), do not necessarily develop organically but must be learned. To this end, the educational activities at primary, secondary and tertiary level are required.

Structural barriers to intercultural dialogue include discrimination, poverty and marginalisation of minority groups; language issues and intolerance and opposition by groups and individuals who advocate hatred and violence towards the perceived "Other". "Othering" is also not a process only engages in by members of the majority culture; it may also occur within minority culture groups. To counter these barriers, leadership and vision is required from those in positions of power and influence. All citizens need to be equipped with the requisite intercultural skill and language plays a central role in this concept as dialogue is not possible without a common language. At the same time, native languages should be taught to contribute to the general wealth of the broader society, and to enable a deeper intercultural dialogue between members of majority and minority groups. A culturally neutral framework needs also to be developed in which members of majority and minority groups can interact: here members of minority groups should learn the language of the majority group, and, that intercultural dialogue is enacted on macro, meso and micro levels.

Criticism of interculturalism includes that intercultural dialogue cannot address structural issues such as discrimination, however, its proponents point out that this is a 'naïve' understanding of interculturalism as it does require structural action by those in power. Another criticism labelled as naïve ${ }^{41}$ is that cultural groups are not homogenous, have unclear boundaries influenced by other cultures, that they shift according to context and this makes an identification of the cultures which are

\footnotetext{
${ }^{40}$ Kymlicka, W., 2015. Defending Diversity in an Era of Populism: Multiculturalism and Interculturalism Compared. academia. edu, https:// www. academia. edu/11038453/Defending_Diversity_in_an_Era_of Populism_Multiculturalism_and_Interculturalism_Compared_2015, consultéle, 10.

41 Barrett, M., 2013, p. 30.
} 
supposed to be in dialogue impossible to identify. This criticism has been rejected as while it may apply to simplistic formulations of intercultural dialogue, more sophisticated versions such as the Council of Europe White Paper (2008) recognise that individuals are autonomous agents with different and complex affiliations, and that intercultural dialogue takes place on an individual level to enhance the individual's intercultural experiences and affiliations.

More substantive criticism includes the issue of power relations between majority and minority groups, pointing to the fact that legal frameworks and culturally sensitive policies to ensure that there is no domination of minority groups through the majority group need to put in place for interculturalism to work. ${ }^{42}$ Another criticism is that of selective intercultural openness (i.e. there may be openness towards certain cultures but not others such as Muslims). This also includes global interculturality versus local interculturality whereby individuals may display a positive attitude towards a different culture on a global level but negative attitudes towards members of the same cultural group living at a local level. These attitudes need to be acknowledged and addressed. The final and most serious criticism, as Barrett 43 argues, is that of interculturalism just being a version of multiculturalism. In particular, Meer and Modood ${ }^{44}$, have made the point that multiculturalism already includes all the qualities, some of them as foundational elements, proponents of interculturalism claim as superior for their approach.

These and other arguments have been debated vigorously but without consensus being achieved over the last two decades.

\section{Multiculturalism in Australia}

The debate about multiculturalism is largely set within the European and North American context; and while attacks on multiculturalism can also be found in Australia, the official discourse has generally seen it as a success. On the other hand, as Armillei ${ }^{45}$ points out, Australia has an indigenous population which does not see itself as part of the multicultural discourse. In fact, while still in the position of living "on the frontier" in their own country, Aboriginal people don't consider themselves as belonging to an ethnic group among the others.

Australian multiculturalism is based on planned migration, and while European migration dominated in the post-World War II period, this has changed considerably in the last few decades. Australia hosts migrants from over 180 different countries of origin and more than 200 languages are spoken. It thus has a greater population diversity, from European to Asian countries, no large minority blocs like US and while often compared to Canada, it does not have to deal with the Anglo-French duality Canadian multiculturalism must accommodate.

Australia is one of the most multicultural societies globally. At $30 \mathrm{~J}$ une 2015, 28.2\% of Australia's estimated resident population (ERP) (6.7 million people) was born

\footnotetext{
42 Kymlicka, W., 2015.

43 Barrett, M., 2013, pp. 30-31.

44 Meer, N. \& Modood, T., 2012.

${ }^{45}$ Armillei, R., 2012, A community within and between communities: Multiculturalism, education, and the experience of Romani people in Australia. Pedagogia oggi, 1(5), pp.1-77.
} 
overseas $^{46}$. Initially, assimilation was the state-sanctioned method of migrant integration in Australia (also known as 'White Australia policy') but from the late 1960s a shift away from assimilation to integration occurred. This was partly due to the line of argumentation that better integrative outcomes could be achieved if the social-cultural and not only economic value of migrants were acknowledged ${ }^{47}$.

It has been postulated that Australian multiculturalism was a response to the recognition of migrant disadvantage in particular in the areas of language and employment and a realisation that migrants might not want to give up their cultural identity $^{48}$. Moreover, it has also been argued that the realisation by the Australian Labor Party (ALP) that ethnic communities represented a sizable number of votes led to an engagement in particular in relation to the Greek and Italian communities, to capture as much of the ethnic vote as. ${ }^{49}$

Multiculturalism "as the basis for migrant settlement, welfare and social-cultural policy in Australia" was first mentioned in 1973 in a speech by Al Grassby, the Minister for Immigration under the Whitlam Government, entitled "A Multi-Cultural Society for the Future". 50 The so-called Galbally report was considered the "foundation document of multiculturalism"51: in 1978 the conservative Australian Government engaged Frank Galbally to chair a commission to review migrant services. The resulting report entitled Migrant Services and Programs: the Report of the Review of Post-Arrival Programs and Services to Migrants emphasised the need to provide encouragement and assistance for migrants to improve their overall situation and to enable them to maintain their cultural identity. The report led to the establishment of a number of initiatives such as interpreting and translation services, migrant resource centres to enable ethnic communities and voluntary agencies to take care of migrant welfare needs, the Australian Institute of Multicultural Affairs, multicultural radio and television services, SBS, the extension of the Adult Migrant English Program (AMEP), and the introduction of multicultural education in schools. Yet, as $\mathrm{Ho}^{52}$ points out, the focus on ethnic disadvantage and migrant welfare ultimately directly related disadvantage to deficiencies within the ethnic groups themselves and restricted multiculturalism to addressing the disadvantage only, and not its systemic causes.

The Galbally report's emphasis on the superior ability of ethnic community organisations and voluntary agencies for service delivery suited the government's agenda to contain costs and thus service provision moved from governmental agencies to voluntary organisations, shifting it from the political to the civic sphere.

Labor, when it took office in 1983, focused its policy on bringing migrant services back into the mainstream, and on the removal of barriers to participation based on ethnicity and gender. The Jupp Review of migrant and multicultural programs and

\footnotetext{
${ }^{46}$ Australian Bureau of Statistics. (2015). 3412.0 - Migration, Australia, 2014-15. Retrieved from http:// www.abs.gov.au/ ausstats/abs@.nsf/mf/3412.0/ , accessed 22122016.

47 Jakubowicz, A. \& Ho, C. 2013, p. 7.

${ }^{48}$ Koleth, E., 2010, 'Multiculturalism: A review of Australian policy statements and recent debates in Australia and overseas', Research paper no. 6 2010-2011, Parliamentary Library, Canberra.

49 Bommes, M., Castles, S. \&Withol de Wenden, C., 1999, 'Post-1947 migration to Australia and the socio-political incorporations of migrants', IMIS Beiträge, vol. 13, pp. 13-42.

50 Koleth, E., 2010, n.p.

51 J upp, J ., 2002. From white Australia to Woomera: The story of Australian immigration. Cambridge

University Press, p. 87.

52 Ho, 2013, p. 33.
} 
services released in 1986 focused on ensuring equal opportunity for all Australians by providing basic resources and support for cultural expression. One of the outcomes of the report was the establishment of the Office of Multicultural Affairs (OMA). Integrating migrant services into the mainstream also removed some of the dominance privileged migrant organisations had enjoyed. Multiculturalism increasingly was seen as a policy applicable to all Australians. ${ }^{53}$

The focus of multicultural policy shifted from migrant settlement services to an emphasis on the economic benefits of cultural diversity. Emphasising economic benefits was an effective way of legitimising cultural diversity in the eyes of the public, especially at a time of economic downturn when public anxiety about migration, cultural diversity and multiculturalism found its expression in discourses about the "Asianisation of Australia". 54

In response to criticisms in particular on Asian immigration, the Committee to Advise on Australia's Immigration Policies (CAAIP), was established in 1987. Its 1988 report firmly put the emphasis on skilled migration and a reduction in services for migrants. The main emphasis, however, was on national identity and migrants' commitment to Australian values and way of life ${ }^{55}$. In response to the report's recommendations multiculturalism shifted to the rights and responsibilities of citizens in the context of a commitment to Australia and Australian values.

This focus also found its way into the 1989 National Agenda for a Multicultural Australia. It was based on three elements: cultural identity-all Australians were to be able to express and share their cultural identity; social justice-equality of all Australians regardless of race, creed, gender origin; economic efficiencymaintenance and development of skills for all Australians.

Key initiatives included the National Policy on Language (1987), which encouraged the learning of foreign languages of economic significance (in particular Asian languages) as well as maintaining community languages, and the establishment of the National Office of Overseas Skills Recognition in 1989. In 1992, the Keating Government-building on the National Agenda-introduced the concept of productive diversity, that is capitalising on the linguistic and cultural skills, business networks and market knowledge of Australia's diverse population. ${ }^{56}$ The concept of productive diversity repositioned multiculturalism from social justice issues to a national economic benefit.

In 1996 the Liberal Coalition government with J ohn Howard as Prime minister came to power, and with it the absorption of many migrant services and institutions into main stream services and a return to a pro- British mindset. By reducing the numbers of Non-English Speaking Background (NESB) migrants and thus decreasing the number of those who might succeed easily in the Australian labour marked, the government was able to reduce costs of migrant settlement. The increasing emphasis on skills resulted in a reduction of multicultural programs. The 1999 New Agenda for Multicultural Australia redefined the principles of multiculturalism from one of support for ethnic groups and migrants to one with an emphasis on national values,

\footnotetext{
${ }^{53}$ Ho, C. 2013, p 35.

54 See page 66.

55 Wende, A.-K., 2010, p. 91.

56 Ho, C. 2013, p 36.
} 
civic duty, and integration into mainstream culture. This shift found its representation in the introduction of the 2007 Citizenship test to ensure societal cohesion and migrant integration. Australia's policy here followed the international trends involving reassertion of the nation state. ${ }^{57}$

Neither the 2007 election of a Labor government nor the 2013 election of a Liberal Coalition Government seems to have wrought much change in multicultural policy. Historically speaking, while in the early days of Australia's planned migration program, assimilation was the preferred method of integrating a predominantly white migrant population, from the early 1970s onwards multiculturalism in its evolutionary phases became part and parcel of the Australian way of dealing with cultural diversity.

And while public discourse has (again) shifted to a more assimilationist model of integration through the (re)introduction of Australian values on a political level, moving citizenship from the instrumental/legal definition closer the emotional/symbolic legal dimension, this is somewhat contradictory to everyday multiculturalism as usually practised in Australia which still celebrates diversity ${ }^{58}$ At the grassroots level multiculturalism is part of everyday Australian life, that is at a local level in shopping centres, streets, suburbs people acknowledge otherness and live with it in the situational context.

\section{A shift in public discourse but continuity in policy?}

A number of scholars ${ }^{5960}$ have pointed out that in public discourses a retreat from the term multiculturalism can be observed. However, it is less clear what this retreat entails. Vertovec and Wessendorf ${ }^{61}$ conclude that the terms multiculturalism and interculturalism are often used interchangeably in policy documentation, thus the shift in terminology may conceals continuities in policy.

While it is undeniable that in the public discourse in western democracies there has been a shift towards an emphasis on greater civic integration, responsibilities of citizenship and civic duties of minority groups, with a number of western countries introducing mandatory civic integration courses inclusive of language components, host country history and values, which require successful completion and have an impact on residency rights, access to social and other services, a comparison of the multicultural policy position of European countries shows that on a macro level, there has been little change in most European countries.

In 2006 Banting and Kymlicka62 assessed the extent to which a particular country has or has not adopted multiculturalism based on a number of policies. The policies included:

\footnotetext{
${ }^{57}$ Klapdor, M., Coombs, M. \& Bohm, C., 2009, pp. 18-19.

58 Voloder, L, 2011, 'Avenues for Belonging: Civic and Ethnic Diemensions of multicultural citizenship in Australia' in F. Mansouri \& M. Lobo (eds.), 2011. Migration, Citizenship, and Intercultural Relations: Looking Through the Lens of Social Inclusion. Ashgate Publishing, Ltd.

59 J oppke, C., 2004, 'The retreat of multiculturalism in the liberal state: theory and policy.' The British journal of sociology, 55(2), pp.237-257.

60 Tilbury, F., 2007, The retreat from multiculturalism: The Australian experience.' Pluralism, Inclusion and Citizenship, 3rd Global Conference, Interdisciplinary. net, Salzburg.

${ }^{61}$ Vertovec, S. \&Wessendorf, N. 2010, p. 18.

62 As cited in Barrett, M., 2013, pp. 16-17.
} 
- the constitutional, legislative or parliamentary affirmation of multiculturalism at the central and/ or regional and municipal levels;

- the adoption of multiculturalism in the school curriculum;

- the inclusion of ethnic representation and sensitivity in the mandate of public media or media licensing;

- exemptions from dress codes on religious grounds;

- the allowing of dual citizenship;

- the funding of ethnic group organisations or activities;

- the funding of bilingual education or mother-tongue instruction;

- affirmative action for disadvantaged immigrant groups.

The authors then proposed that for each feature, a score of either 1 (clear policy), 0.5 (partial policy) or 0 (no such policy) should be awarded and that by totalling the score the Multiculturalism Policy Index for that country could be established. Countries scoring between 6 and 8 were considered strongly multiculturalist, countries scoring between 3 and 5.5 modestly multiculturalist, and countries scoring between 0 and 2.5 were weak on multiculturalism.

In 2010 Banting and Kymlicka63 using this classification made the following findings:

- $\quad$ strong on multiculturalism: Australia, Canada, Finland, Sweden;

- modest on multiculturalism: Belgium, Ireland, Norway, Portugal, Spain, United Kingdom;

- weak on multiculturalism: Austria, Denmark, France, Germany, Greece, Italy, Netherlands, Switzerland.

Overall, the study found that between 2000 and 2010 multicultural policies were not substantially scaled back in most European countries and in some cases seemed to have been strengthened while in the public discourse a retreat from multiculturalism was proclaimed. Assigning scores to countries on the strength of their policies, Banting and Kymlicka found that only three European countries showed a retreat from multiculturalisms expressed in a lower score in 2010 than in 2000. These countries were Denmark and the Netherlands, two very liberal countries which have moved on from their liberal positions in other areas such as social security provisions and health care in general, and Italy, which had never adopted a multicultural stance.

So while the political and public discourse has become far more critical of multiculturalism, policies and individual opinion have not changed substantially in the last 10 years in the European and North American contexts as the examples below show; rather changes can be seen as evolution of the concept.

Canada, one of the two most multicultural and poly-ethnic countries in the world, provides a good example of the historical dimension of the different stages of multicultural policy development: Kunz and Sykes 64 have identified the following phases of multiculturalism: The 1970s were dominated by so-called ethnic multiculturalism; its main features were the celebration of ethnic diversity and cultural differences with a policy focus on overcoming prejudice through cultural

${ }^{63}$ Banting, K. \& Kymlicka, W., 2013, 'Is there really a retreat from multiculturalism policies; New evidence from the multiculturalism policy index.' Comparative European Politics, 11(5), pp. 577-598.

64 Sykes \& Kunz 2007 as cited in Barrett, . 2013, pp. 19-20. 
sensitivity and an acknowledgment of cultural diversity as a positive. The 1980s were characterised by what the authors call "equity multiculturalism", focusing on eradicating systemic discrimination on the basis of ethnicity, with the removal of barriers to economic participation, employment equity and cultural accommodation as the overarching policy goals. The 1990s saw a shift to civic multiculturalism marked by a focus on engagement, shared citizenship and belonging. The major issue was social exclusion to be tackled through participation and an inclusive society. The 2000s finally, marked by global ethnic and religion- based conflicts saw the emergence of a call for an integrative form of multiculturalism, based on the perception of a need for greater mutual understanding and intercultural dialogue.

Britain had long been a poly-ethnic society due to its colonial past with racially-based violence not uncommon (e.g. riots in Notting Hill 1958; Handsworth 1980; Brixton, 1981; Chapeltown, Leeds, 1981;Blackburn, Burnley, and Coventry, 1992; Bradford 1995). While initially the "bad other" was represented by the young Caribbean male, by the 1990s this had been supplanted by the "Muslim Other"65. The 2001 Twin Towers attack and the subsequent "War on Terror" gave rise to fear, and community cohesion became the new watch word. The 2005 London bombings aggravated these fears situation and with the election of a conservative government in 2010 "the language of social cohesion intensified and the antipathy to multiculturalism intensified". 66 By 2011 British Prime Minister David Cameron officially denounced multiculturalism as an agent of segregation, and blamed politically correct, hands-off policy for the state of affairs. By 2012, religion had entered the debate as defining factor with a call to centre civic values on Christian values. In 2016 the UK decided to sever its ties with the EU, the campaign fought to a great extent on issues of migration, the presence of the "Other" and their access to British (social) services.

France as a former colonial power had to absorb a large number North African immigrants and at the beginning of the 1980s went through a short phase of a multiculturalism; the so-called March for Equality in 1983 and a repeat the following year showed the desire of especially young people of immigrant background for equality and recognition, however, this phase did not result in a change to the French framework of migrant incorporation because multiculturalism is seen as a threat to national identity and republican values. Thus, 'integration' has been adopted as the preferred model in France. This is based on a number of essential principles. Becoming a French citizen is the preferred endpoint of incorporation, thus making integration an individual process. In the French model " the concept of integration is linked to the principle of equality in that it tries to enforce the practice of equality in social life". 67

Germany also had a sizeable foreign population. The so-called guest workers, hired during the economic boom times of the 1960s and expected to return to their home countries once they were no longer needed, instead elected to stay. It was only in 1990s-2000s that the reality of having a non-native German population was acknowledged. On the level of policy two divergent and almost mutually exclusive

\footnotetext{
65 J akubowicz, A., 2013. Comparing Australian multiculturalism: the international dimension.’ In A. Jakubowicz \& C. Ho (eds.), 2013, For Those Who've Come Across the Seas...": Australian Multicultural Theory Policy and Practice, pp.15-30.

66 J akubowicz, A., 2011, p. 21.

67 Simon, P. and Pala, V.S., 2010. "We are not all multiculturalist yet": France swings between hard integration and soft antidiscrimination.' In Vertovec, Steven und Susanne Wessendorf (eds.), 2010, The Multiculturalist Backlash. European discourses, policies and practices. London, Routledge., pp. 92-93.
} 
approaches were adopted: on the hand "integration" which took the form of assimilation, i.e. the necessity to speak German and melt into the German community, thus becoming indistinguishable; the other approach was to celebrate diversity. While never a multicultural society, high unemployment in the late 1990s led to accusations that multiculturalism stifled critical voices branding them "racist" without engaging with the criticism while at the same time condemning migrant communities as rejecting the value of integration and reciprocity. September 11 led to a further worsening of the situation. Until then there had been recognition that the immigrants were marginalised through social and cultural structures; from that point onwards it became the failure of the immigrants themselves and their desire to remain apart from the German system and values.

While Europe has ostensibly moved away from multiculturalism, as the above examples indicate, identifiable practices persist. It is important to distinguish the different levels. Attacks on multiculturalism are common on an ideological level and, to a degree, this carries through on a policy level, i.e. the nation states reasserting national values. What Jakubowicz has called the "dominance of the national paradigm"68 finds its expression in citizenship tests, ceremonies and oaths, and the idea of Europe under attack from alien forces. However, as Banting and Kymlicka's 2013 study shows, multicultural policies and practices are still in place and in the main have not been significantly watered down.

Other, more recent scholarship, comes to similar conclusions. Meer and others 69 argue that the development of multiculturalism in different national contexts is not linear "that where there have been advances in policies of multiculturalism, these have not been repealed uniformly, nor on occasion at all, but may equally have been supplemented or "balanced out" in, or thickened by, civic integrationist approaches." Hooghe and de Vroome ${ }^{70}$ in their exploration of the European public's attitudes towards multiculturalisnism come to the conclusion it there is support for "the notion that different mechanisms could be at work among different sections of the population" , as outlined by authors, that there is not a singular "public" and that attitudes seem to be influenced by a number of factors such as level of education and social capital and economic mobility and status.

\section{Conclusion}

Despite the fact that interculturalism as a concept is relatively unknown in Australia, commitment to multiculturalism by government has not changed and multiculturalism in general is viewed as a success, Australia has seen similar criticism levelled at multiculturalism as European and North American countries.

Major points of criticism in the Australian context included that it has failed to acknowledge and deal with the fact that diversity is not limited to race/ ethnicity and these are not the only modes of social exclusion and the basis of social and political identity ascription.

\footnotetext{
68 Jakubowicz, A., 2013, p. 26.

69 Meer, N., Mouritsen, P., Faas, D. and de Witte, N., 2015. 'Examining 'Postmulticultural'and Civic Turns in the Netherlands, Britain, Germany, and Denmark.' American Behavioral Scientist, 59(6), pp.702-726, p. 721.

70 Hooghe, M. \& de Vroome, T., 2015. 'How does the majority public react to multiculturalist policies? A comparative analysis of European countries.' American Behavioral Scientist, 59(6), pp.747-768, pp. $764-765$.
} 
On a less theoretical level, a key criticism by groups situated on the right/nationalist side of politics is that migrants are granted access to the same rights and services as citizens but do not share the same responsibilities. While on a factual level, this criticism does not hold up to reality, it is nevertheless a common perception. Another common perception is that multiculturalism increases the possibility of "homegrown terrorism", especially by the "Muslim Other" whose culture is often seen as incompatible with western cultures.

Issues of social cohesion and inclusion have been noted for Australia in the same way as for Europe and North America. These were particularly driven by the economic impact of globalisation, increasing mobility of people from diverse cultures, concerns over terrorism, loyalty to Australian values, and violence in urban areas linked to religion and/migration. Marcus ${ }^{71}$ concludes that there is some evidence that social cohesion in Australia is under increasing stress. This may be linked to the severity of national and international problems and the combative nature of political debate, characterised by denunciation of political opponents, dogmatic advocacy of simplistic policies and public endorsement of intolerance.

As Australia seems to face similar criticism regarding multiculturalism and similar problems of social cohesion as encountered in European/North American countries which have retreated from multiculturalism ${ }^{72}$, why is multiculturalism still promoted as a success and there does not seem to be a retreat in public discourse?

As outlined above, while a retreat from the term has been noted in particular in Europe, there has not been a concomitant retreat from multicultural policies. At a grassroots level people still live 'in' diversity not only in Australia ${ }^{73}$ but elsewhere. This discrepancy may point to the veracity of Kymlicka's contention that the shift in terminology may just be a convenient political myth, a narrative to enable a continued approach to inclusion while seemingly responding to some section of the public's concerns. ${ }^{74}$

\footnotetext{
${ }^{71}$ Marcus, A., 2011, 'Social Cohesion/social inclusion in Australia,' in F. Mansouri \& M. Lobo (eds.) 2011. Migration, Citizenship, and Intercultural Relations: Looking Through the Lens of Social Inclusion. Ashgate Publishing, Ltd, p. 158.

${ }^{72}$ As outlined elsewhere, changes to the Australia's citizenship regime and introduction of a citizenship test follow the European experience, so a certain retreat can be found in Australia as well.

${ }^{73}$ See J akubowicz, A., 2011, and Vertovec, S. \&Wessendorf, S., 2010.

74 Kymlicka, W., 2012, p. 213.
} 